present Government. It is therefore sincerely to be hoped that the forthcoming Exhibition at Edinburgh will be the means of putting a new spoke in the wheel, and that before the close of the Exhibition, or soon after, something tangible may have resulted in making forestry one of the branches of education either in distinctly constituted forest schools, or in our present agricultural colleges.

It is satisfactory to know that the arrangements of the Exhibition are in a forward state, and that, if the promises which have been received by the executive are fulfilled, the Exhibition will exceed the anticipations of the promoters.

JOHN R. JACKSON

\section{RAINFALL OF NEW SOUTH WALES}

$\mathrm{U}$

NDER the energetic direction of Mr. Russell the investigation of the rainfall of New South Wales is being prosecuted with much success, and the interest of the colonists may now fairly be regarded as awakened to the importance of the inquiry. This is evidenced by the recent rapid increase of stations, the number of rain stations for the five years ending 1882 being 96, I 53, I9I, 256 , and 308 , having thus trebled during this brief interval. A comparison of the maps of stations for 1878 and 1882 shows that the increase has been pretty evenly distributed over the whole colony; and of particular importance is it to note the spread of the rain-gauge over the extensive regions which lie to the north and north-west of the Murray River.

Mr. Russell draws pointed attention, in the following extract, to the practical value to the colonists of well kept rain registers :-

"As a proof of the necessity for the use of the rainyauge all over the colony, not only for purposes of science, but also as a necessary instrument on every run, I may mention that on Goolhi station six gauges are kept on various parts of the run, and the records range from $19.8 \mathrm{I}$ inches to 27.75 inches. It would obviously lead to a false estimate of the grass the run would produce if only one gauge had been used, and that one where only 19.81 inches were recorded. 'I hope that the facts which the yearly records bring to light will have the effect of awakening those interested to the immense importance of collecting these statistics carefully. and at once, so that every year will add to the knowledge which will be of such value in forming estimates of the seasons which are to come, and of the possibility of conserving water."

Lately much speculation was indulged in, and various schemes were proposed of increasing by artificial means the rainfall of $\mathrm{New}$ South Wales, particularly in seasons of drought when day after day the sky becomes covered with dark, dense-looking clouds which regularly pass away without a drop of rain. In these cases, science can as yet hold out no hopes to the agriculturist. The successful instances of rain-production by artificial means have occurred when the atmosphere in the district where the experiment was made was at or near the point of saturation, a state of things which does not exist in the arid plains of the interior of Australia under the meteorological conditions when clouds daily darken the skies and as regularly mock the expectation of the farmer.

It must then be to a judicious and skilful cropping of the rainfall that the Australian farmer must look for the supply of his wants in the dry season and still more in seasons of exceptional drought. Now, as contributions towards the solution of this problem, the annual rainfall reports of Mr. Russell are simply invaluable. These reports give the rainfall and total days of rain for each month and for the year, to which is added the mean annual rainfall and rainy days calculated from previous years' observations at each place available for the purpose.

1 "Results of Rain and River Observations made in New South Wales during $187^{8-82 . " ~ B y ~ H . ~ C . ~ R u s s e l !, ~ B . A ., ~ G o v e r n m e t n ~ A s t r o n o m e r ~ f o r ~ N e w ~}$ South Wales.
The annual rainfall for each year is represented on a large map of the colony, 22 by 26 inches, where the fall for each station is entered in its place as a black spot, the diameter of which is proportioned to the quantity of rain. By this device, the eye takes in readily and at a glance the distribution of the rainfall for the year. The comparative results of the five years for the different districts of the colony are most instructive.

Owing to its position on the globe and its physical con figuration, New South Wales presents extremely different climates according to the varying amounts of the rainfall. Thus at Antony, on the coast ncar the borders of Queensland, the mean annual rainfall amounts to $65^{\circ} 15$ inches ; whereas at Mount Poole, in the extreme north-west, it is only 8.38 inches. For the nine years beginning with 1874, an approximation to the annual rainfall of the colony for each ycar has been calculated by Mr. Russell, the results for the separate years being $33^{\circ} 46,29^{\circ} 3^{\circ}, 27^{\circ} 66^{\prime}$, $20^{\circ} 48,25^{\circ} 05,30^{\circ} 75,19^{\circ} 93,20^{\circ} 73$, and $20^{\prime}$ I I inches, each of the last three years showing a marked deficiency. Now the interesting point is this, and it is a peculiarity which every other country possesses, but particularly those which exhibit climates so diversified as New South Wales, viz. that the rainfall of any month, or of any year, is very far from being equably distributed. The amounts of the excesses above, or the defects from, the average, tend really to partition the country into several well-defined rain districts for the time, these being determined apparently by river basins, watersheds, and other features of its physical configuration taken in connection with their relations to the thunderstorms and the rain-bringing winds. It is quite in the future, as an outcome of Mr. Russell's work, that the settlers in different parts of the colony will receive specific directions as to the cropping of their rainfall so as to provide even against the recurring calamitous droughts of the Australian climates.

An interesting feature of the reports are the diagrams, showing, by curves, the heights for cach day of the Darling, Murrumbidgee, and Murray Rivers. A heavy flood occurred at Bourke, on the Darling River, on February 4, 1882, and reached its maximum, 26 feet 2 inches, by the end of the month, and the river did not fall to its summer level until April 5. This flood was occasioned by heavy tropical rains, from Fcbruary 1 to 7 , that fell over the northern part of the I arling watershed, which took two months to drain off, as is proved by the fact that little or no rain fell during the latter half of February and all March. In a few years these systematic observations of the heights of the principal rivers of Australia will furnish invaluable data for the determination of not a few important problems of meteorology and physical geography, which the marked insular character of this continent is so well suited to elucidate.

\section{CALCUTTA BOTANIC GARDEN}

5 IR JOSEPH HOOKER has kindly placed at our $D$ disposal the following letter on the Calcutta Botanic Garden :--

"Our beautiful garden is now looking very nice. Let me tell you what I am looking out upon. On the right is a fine Terminalia Catappa, a mass of dark green foliage from base to summit, its branches with a quantity of Soranthus longifloms on them. Further off, towering in the distance, is a clean-stemmed, stately-looking Dipterocarpus alatus, its branches the roost of vultures and cheels. Almost as tall, to one side of the Dipterocarp, is a beautiful Terminalia Arunja, with mahoganies and the golden-flowered Peltophorum in front. Dillenia pentagyna in front, and Morinda tinctoria covered with masses of Vanda Roxburghii. There is a fine Adina cordifolia, one of the monarchs of the garden ; its straight, strong stem, disdaining to bend in the sudden squalls and rain-storms, bears evidence of having been topped before, 
and I am always expecting to see it go. At its feet cluster our bed of Cycads, the latter shaded by young Oreodoxas and Caryotas, and with the margin of the bed fringed by the long feathered leaves, plume-like, of Phonix rupicola. Here and there gleams of silver catch the eye, as the sun, striking on the ornamental stretches of water, glances through the foliage. To the left another member of that beautiful section of the Rubiaced-the Nauclea-occupies a prominent place, its stem the home of the handsome blossoms of Vanda teres. The pretty marble pillar and urn to the memory of Col. Kyd is seen through the branches. From it roads lead to the principal landingstage bordered by Oreodoxas, mahoganies, and our only attempt at ribbon gardening, long lines of Acalyphas, \&c. Another road, straight for nearly, if not quite, half a mile to one of the exits, has an avenue of Polyalthia longifolia, sacred to the Hindoos, and groups of Betle palms; then of Oreodoxas, and lastly of Inga Saman. We have great difficulty with the Oreodoxas on account of a beetle that lays its eggs in the terminal buds. Still another road leads to the Orchid House bordered by clumps of graceful bamboos. In the house we generally manage to have a pretty show, and its neighbourhood in the proper season is gay with the blossoms of Amherstia Gustavia, Thunbergia Napoleona, \&c. Magnoiza grandifora is flowering with us just now. What a glorious flower it is! Yesterday and the day before there came down on us one of the sudden miniature cyclones that we are so liable to have at the approach of the change of the monsoon. It blew, rained, and hailed tremendously. The trees tossed their arms and wailed, poor things, with such effect that their branches everywhere broke and strewed the ground. However only one small mahogany fell. It was quite cold, and the rain froze, as it was falling, into lumps as big as marbles."

THE EXTINCT LAKES OF THEGREAT BASIN

THE Great Basin of North America presents the most singular contrasts of scenery to the regions that surround it. East of it rise the dark pine-covered heights of the Rocky Mountain system, with the high, bare, grassy prairies beyond them. To the west tower the more serrated scarps of the Sierra Nevada, with the steep Pacific slope on the other side. The traveller who enters the Basin, and passes beyond the marginal tracts where, with the aid of water from the neighbouring mountains, human industry has made the desert to blossom as the rose, soon finds himself in an arid climate and an almost lifeless desert. The rains that fall on the encircling mountains feed some streams that pour their waters into the Basin, but out of it no stream emerges. All the water is evaporated; and it would seem that at present cven more is evaporated than is received, and that consequently the various lakes are diminishing. The Great Salt Lake is conspicuously less than it was a few years ago. Even within the short time that this remarkable region has been known, distinct oscillations in the level of the lake have been recorded. There are evidently cycles of greater and less precipitation, and consequently of higher and lower levels in the lakes of the Basin, though we are not yet in possession of sufficient data to estimate the extent and recurrence of these fluctuations.

It is now well known that oscillations of the most gigantic kind have taken place during past time in the level and condition of the waters of the Great Basin. The terraces of the Great Salt Lake afford striking cvidence that this vast sheet of water was once somewhere about 1000 feet higher in level, and had then an outflow by a northern pass into the lava deserts through which the cañons of the Snake River and its tributaries wind their way towards the Pacific. Mr. Clarence King, Mr. Gilbert, and their associates in the Survey of the 4oth Parallel, threw a flood of light upon the early history of the lake and the climatic changes of which its deposits have preserved a record. They showed that the present Great Salt Lake is only one of several shrunken sheets of water, the former areas of which can still be accurately traced by the terraces they have left along their ancient margins. To one of the largest of these vanished lakes the name of the French explorer Lahontan has been given. The geologists of the 4oth Parallel Survey were able to portray its outlines on a map, and to offer material for a comparison between it and the former still larger reservoir of which the present Great Salt Lake is only a relic. The United States Geological Survey has since begun the more detailed investigation of the region, so that ere long we shall be in possession of data for a better solution of some of the many problems which the phenomena of the Great Basin present. In the meantime Mr. J. C. Russell, who has been intrusted with this work, has written an interesting and suggestive preliminary report of his labours.

The average rainfall of the area of the Great Basin is probably not more than 12 or 15 inches. In the more desert tracts it may not exceed 4 inches, though in the valleys on the borders of the Basin it may rise to 20 or 30 inches. The rain falls chiefly in autumn and winter, consequently many of the streams only flow during the rainy season, and for most of the year present dry channels. Even of the perennial water-courses, the larger part of their discharge is crowcled into a brief space towards the end of the rainy season. Most of the streams diminish in volume as they descend into the valleys, and many of them disappear altogether as they wander across the blazing thirsty desert. Loaded with sediment, and more or less bitter with saline and alkaline solutions, they do little to redeem the lifelessness of these wastes.

Over the lower parts of the surface of the Basin are scattered numerous sheets of water. Where these have an outflow to lower levels they are fresh, as in the examples of Bear Lake, Utah Lake, and Tahoe Lake. But the great majority have no outflow. Some of them are merely temporary sheets of shallow water, appearing after a stormy night, and vanishing again beneath the next noonday sun, or gathering during the rainy season, and disappearing in summer. Yet in some cases these transient lakes cover an area of roo square miles or more. When they dry up, they leave behind them hard smooth plains of grayish mud, that crack up under the burning sun, and then look like a broken mosaic of marble. Of the permanent lakes the largest is the Great Salt Lake. It is also by much the most saline. Though all of them are more or less charged with alkaline and saline solutions, the percentage of these impurities is in some cases not so great as to prevent the water from being drunk by animals, or even on an emergency by man himself. Nothing in the physics of the Basin is morc remarkable than the great diversity in the amount and nature of the mineral substances in solution in the lakes.

The vanished sheet of water, or "fossil lake," as the American surveyors call it, known as Lake Lahontan, lay chiefly in the north-west part of Nevada, but extended also into California. In outline it was exceptionally irregular, being composed of a number of almost detached strips and basins connected by narrow straits, and sometimes separated only by narrow ridges. It inclosed a rugged mountainous island 126 miles long from north to south, and 50 miles broad, which contained two lakes, neither of them apparently overflowing into the main lake. The Central Pacific Railroad passes for 165 miles through the dried-up bed of Lake Lahontan. From the windows of the car one can look out upon the ancient clay floor of the lake and mark the marginal terraces winding with almost artificial precision along the bases of the hills. The larger basins, which were formerly united into one continuous sheet of water, still hold lakes, all of which are more or less saline and alkaline, but they are far from being such concentrated brines as might be 